\title{
原著
}

上部早期胃癌に対する噴門側胃切除・空腸pouch間置再建術と 胃全摘・Roux-en-Y再建術との比較検討一術後栄養状態の変化一

\author{
独立行政法人国立病院機構大阪医療センター外科 \\ 牧 野 知 紀藤 谷和 正辻 仲利 政 \\ 平尾素宏
}

\section{Comparison of Postoperative Nutritional State between Proximal Gastrectomy with Jejunal Pouch Interposition and Total Gastrectomy with Roux-en-Y Reconstruction for Early Gastric Cancer in the Upper Third of the Stomach}

\author{
Tomoki MAKINO, Kazumasa FUJITANI, Toshimasa TSUJINAKA \\ and Motohiro HIRAO
}

Department of Surgery, National Hospital Organization Osaka National Hospital

はじめに：上部早期胃癌に対する噴門側胃切除・空腸pouch間置再建術の意義を胃全摘・Roux-en-Y再建術と 比較検討した。方法：術前診断T1N0（Stage I A）の上部早期胃癌に対して, 迷走神経温存噴門側胃切除・空腸 pouch間置再建術を施行した12例（以下P群）と胃全摘・Roux-en-Y再建術を施行した14例（以下R群）について， 周術期因子, 術後の栄養状態を比較した。結果：リンパ節郭清においてR群でD2郭清が多かった（ $\mathrm{p}=0.002 ）$ 以 外は，背景因子に両群間で偏りはなかった。周術期因子に関しては，手術時間がP群においてやや長いが（ $p=$ 0.057), 術後在院日数はP群が有意に短かった $(\mathrm{p}=0.037)$ 。術後合併症の頻度は両群間で差はなかった。術後体 重減少率は，P群において術後 6,12 力月目とR群に比べ有意に少なく(それぞれ $\mathrm{p}=0.026,0.031)$, 同様の傾向 が術後 2 年まで続いた。他の栄養指標因子に関しては, 両群間に有意な差は認めなかった。考察：P群は手術時間 は多少かかるが, 術後合併症でR群と差はなく, 術後在院日数・術後体重減少においてR群よりも有利であった。

索引用語：噴門側胃切除術（proximal gastrectomy），空腸pouch間置再建術（jejunal pouch interposion），胃 全摘術 (total gastrectomy)

\section{はじめに}

近年, 噴門部・上部早期胃癌において, quality of life（以下QOL）を考虑した縮小手術としての 噴門側胃切除術の適応例が増加しつつある。しか しながら，噴門側胃切除術の術後QOLに関して， 他術式と比較検討した報告は意外に少なく ${ }^{1) \sim 3)}$, 再建法も含めて術式に関しての評価は定まってい ない。上部早期胃癌に対する迷走神経温存噴門側 胃切除·空腸pouch間置再建術と胃全摘·Roux-en
-Y再建術とを, 周術期因子, 術後の栄養面からretrospectiveに比較検討したので報告する。

\section{対象と方法}

当科にて平成 10 年 15 年に, 術前診断 T $1 \mathrm{~N} 0$ (Stage I A) とされた上部 $(\mathrm{U} \cdot \mathrm{UM} \cdot \mathrm{MU}$ 領域) 早期胃癌に対して, 迷走神経温存噴門側胃切除· 空腸pouch間置再建術を施行した12症例（以下 $\mathrm{P}$ 群）と胃全摘・Roux-en-Y再建術を施行した14症 例 (以下R群)を対象とした。両群間で周術期因子 
(性，年齢，Stage，リンパ節郭清度，根治度，手 術時間, 術中出血量, 術後在院日数), 術後の栄養 指標因子 ( WBC $\cdot \mathrm{Hb} \cdot \mathrm{TP} \cdot \mathrm{T}-\mathrm{Cho}$ 值の推移), 術後体重減少率, 術後合併症, 術後症状 (逆流症状, 嘔吐症状, dumping症状)の有無を比較検討した。

当科における手術術式としては，P群では噴門 側の胃切除範囲は全胃の $1 / 2$ 以下にとどめている。 空腸pouchの作製は, Treitz鞁带より約 $20 \mathrm{~cm}$ 肛側 の部位から $20 \mathrm{~cm}$ 長の有茎空腸腸管を切離し, 横行 結腸間膜を通して挙上した後, 逆U字型になるよ うに自動吻合器にて空腸空腸側々吻合を施行す る。食道と空腸pouch との吻合はECS $25 \mathrm{~mm}$ を用 いて行っている。その際, 逆流防止目的に, 空腸 pouch右前壁に吻合部位を設定するほか, apical bridgeの作製, 空腸pouch上部の吊り上げ（His角 の形成）を施行している。空腸pouchと残胃との吻 合および空腸同士の吻合は, Albert-Lembert法で 施行子る。さらに迷走神経肝枝・腹腔枝は温存し, \#1，2，3，4sa，4sb, 4d(partial), 7, 8a, 9, 11 $\mathrm{p}$ の各リンパ節を郭清するD $1+\alpha$ 郭清を標準術式 として行っている (Fig.1)。

R群では, Treitz鞀带より $20 \mathrm{~cm}$ 肛側の空腸を切 離し, 肛側空腸を結腸間膜を通して挙上した後, 食 道と空腸とをECS $25 \mathrm{~mm}$ を用いて器械吻合する。 吻合部より $40 \mathrm{~cm}$ 肛側に空腸同士をArbert-Lembert法で側端吻合している。R群においては 2 群 リンパ節郭清を標準術式として行っている。なお Stage, リンパ節郭清度抢よび根治度は胃癌取扱 い規約 ${ }^{4} に$ 基づいた。両群ともに退院基準としては, 炎症所見がなく, (5 分粥を 5 割以上) 経口捸取が

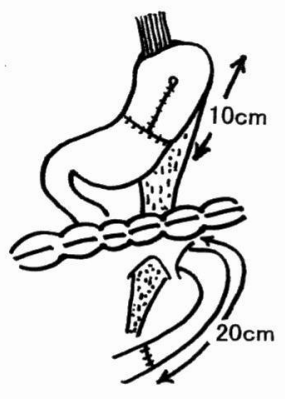

Proximal pouch interposition

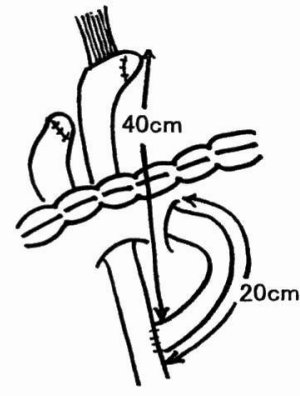

Total Roux-en-Y
Fig. 1 Schematic illustrations of surgical procedures.
可能であることとした。また対象症例の術後観察期 間は24力月間とし, 術後症状は聴き取り調査に基づ いて判定した。両群間の比較において統計学的処理 は, Mann-WhitneyのU検定, $\chi^{2}$ 検定, Fisherの直 接確立法にて行い, $\mathrm{p}<0.05 に て$ 有意差ありとした。

\section{結果}

周術期因子：周術期に扮ける両群間の背景因子 の偏りについて検討した（Table 1, 2)。

性, 年齢, Stage, 根治度に関しては両群間に偏 りはなかった。

手術侵襲に関連する郭清度に関しては, P群で は全例D1郭清である(D2郭清には4dの全郭清が 必要であるため不可能) のに対し，R群ではD1, $\mathrm{D} 2$ 郭清がそれぞれ 4 人, 10 人と $\mathrm{R}$ 群でのD2郭清例 が多かった $(\mathrm{p}=0.002)$ 。また術中出血量は, P群 $287.5 \pm 71.6 \mathrm{ml}$ (mean $\pm \mathrm{SD}$, 以下同様) に対し, R群 $431.8 \pm 278.9 \mathrm{ml}$ であり, 両群間での有意差は なかった。手術時間は, P群263.8 29 .6分に対し てR群230.9土39.1分であり, P群において若干長 い傾向にあった（ $\mathrm{p}=0.057 ） 。$

術後在院日数に関しては, P群 23.0 日 (中央值) に対してR群29.5日であり, R群の方が有意に長か つた $(\mathrm{p}=0.037)$ 。

栄養指標因子：術後の白血球数 (WBC) - 総蛋

Table 1 Clinical characteristics

\begin{tabular}{|l|c|c|c|}
\hline & $P(n=12)$ & $R(n=14)$ & $P$ value \\
\hline Sex (M/F) & $11 / 1$ & $10 / 4$ & N.S. \\
\hline Age (y.o.) & $61.3 \pm 9.3$ & $59.6 \pm 8.4$ & N.S. \\
\hline $\begin{array}{l}\text { Stage } \\
\text { ( I A/ I B/II / II A) }\end{array}$ & $10 / 2 / 0 / 0$ & $10 / 2 / 1 / 1$ & N.S. \\
\hline Dx(D1/D2) & $12 / 0$ & $4 / 10$ & $<0.05$ \\
\hline Cur.(A/B) & $12 / 0$ & $11 / 3$ & N.S. \\
\hline \multicolumn{4}{|c|}{ *mean \pm SD N.S.: not significant }
\end{tabular}

Table 2 Operation time, blood loss and postoperative stay

\begin{tabular}{|l|c|c|c|}
\hline & $P(n=12)$ & $R(n=14)$ & $P$ value \\
\hline $\begin{array}{l}\text { operation time* } \\
\text { (min.) }\end{array}$ & $263.8 \pm 29.6$ & $230.9 \pm 39.1$ & 0.057 \\
\hline $\begin{array}{l}\text { blood loss * } \\
(\mathrm{ml})\end{array}$ & $287.5 \pm 71.6$ & $431.8 \pm 278.9$ & 0.237 \\
\hline $\begin{array}{l}\text { postoperative } \\
\text { stay **(days) }\end{array}$ & 23.0 & 29.5 & $<0.05$ \\
\hline \multicolumn{4}{|c|}{${ }^{*}$ mean \pm SD ${ }^{* *}$ median value } \\
\hline
\end{tabular}



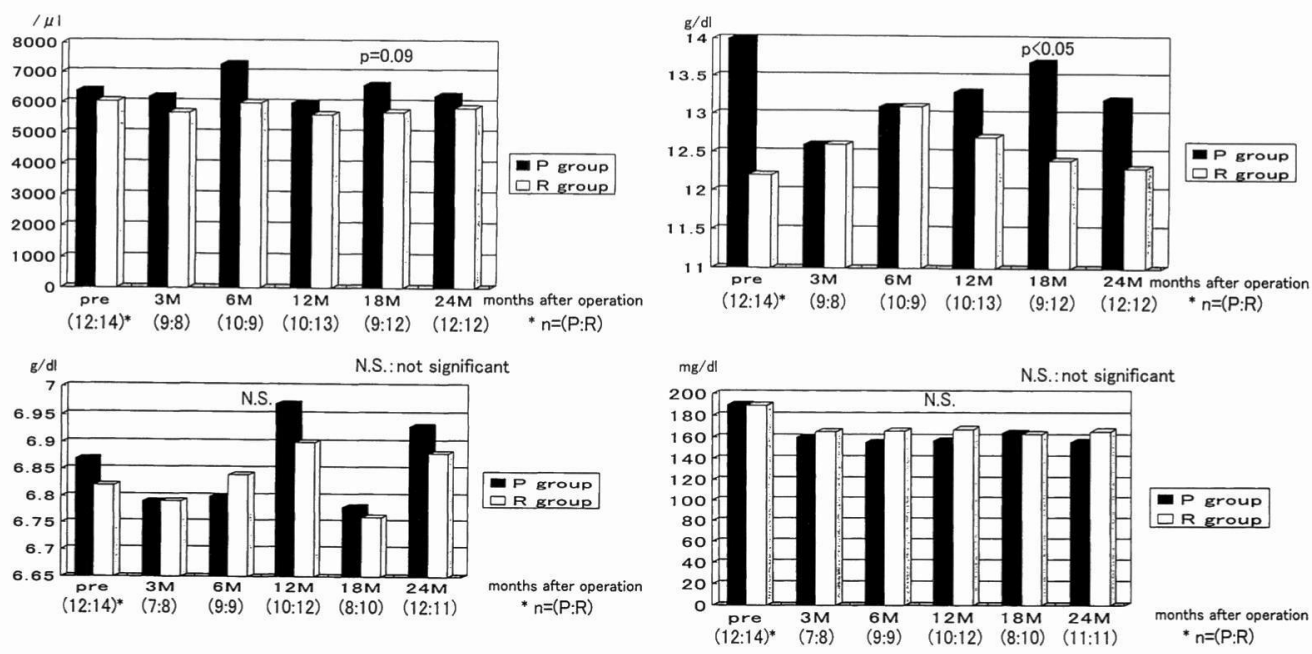

Fig. 2 Postoperative change of white blood cell counts (A), hemoglobin value (B), total protein value $(C)$, and total cholesterol value (D).

\begin{tabular}{l|l} 
A & B \\
\hline C & D
\end{tabular}

\begin{tabular}{|c|c|c|c|}
\hline & \multicolumn{1}{|c|}{$P$} & \multicolumn{1}{|c|}{$R$} & $P$ value \\
\hline $3 \mathrm{M}$ & $\begin{array}{l}89.6 \% \\
(n=12)\end{array}$ & $\begin{array}{l}87.3 \% \\
(n=13)\end{array}$ & 0.12 \\
\hline $6 \mathrm{M}$ & $\begin{array}{l}88.4 \\
(n=12)\end{array}$ & $\begin{array}{l}83.7 \\
(n=13)\end{array}$ & $<0.05$ \\
\hline $12 \mathrm{M}$ & $\begin{array}{l}88.3 \\
(n=12)\end{array}$ & $\begin{array}{l}83.0 \\
(n=14)\end{array}$ & $<0.05$ \\
\hline $18 \mathrm{M}$ & $\begin{array}{l}87.9 \\
(n=9)\end{array}$ & $\begin{array}{l}82.5 \\
(n=12)\end{array}$ & 0.08 \\
\hline $24 \mathrm{M}$ & $\begin{array}{l}86.8 \\
(n=12)\end{array}$ & $\begin{array}{l}83.9 \\
(n=14)\end{array}$ & 0.30 \\
\hline
\end{tabular}

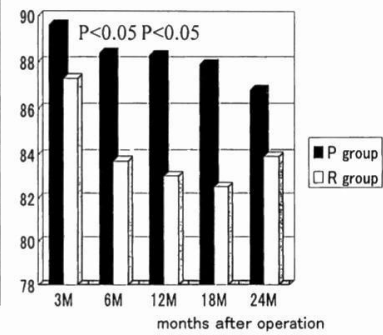

Fig. 3 Postoperative change of body weight ( $\%$ of preoperative body weight*).

白值 $(\mathrm{TP})$ ·総コレステロール值 $(\mathrm{T}-\mathrm{cho})$ に関し ては，両群間に有意差は認められなかった（Fig. $2 \mathrm{~A}, \mathrm{~B}, \mathrm{C}, \mathrm{D})$ 。血中へモグロビン值 $(\mathrm{Hb})$ におい ては術後18力月目にP群が $13.7 \pm 1.6 \mathrm{~g} / \mathrm{dl}$ であり $\mathrm{R}$ 群が $12.4 \pm 1.2 \mathrm{~g} / \mathrm{dl}$ と両群間に有意な差を認めた $(\mathrm{p}=0.033)$ 。

術後体重減少率：術後の体重変化を両群間で比 較すると, 術後 3 力月目の体重 (術前比\%) はP 群

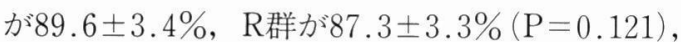

術後 6 力月目ではP群 $88.4 \pm 5.3 \%, \mathrm{R}$ 群 $83.7 \pm 4.8$ $\%(\mathrm{p}=0.026)$, 術後12力月目ではP群が $88.3 \pm 5.5$ $\%$ ， R 群が83.0土4.3\% ( P=0.031), 術後18力月目 ではP群が87.9土6.4\%，R群が $82.5 \pm 5.4 \%(\mathrm{p}=$ 0.076) と術後 1 年目まではP群における術後体重 減少率がR群に比べ有意に少なかった (Fig. 3$)$ 。
Table 3 Postoperative complications

\begin{tabular}{|c|c|c|c|}
\hline$P(n=12)$ & \multicolumn{2}{|l|}{$R(n=14)$} & $P$ value \\
\hline \multirow[t]{3}{*}{$0 / 12(0 \%)$} & \multicolumn{2}{|l|}{$2 / 14(14.3 \%)$} & N.S. \\
\hline & Anastomotic leakage & 1case & \\
\hline & Liver abscess & 1case & \\
\hline
\end{tabular}

同様の傾向は術後 2 年目まで続いた。

術後合併症：P群では合併症がなかったのに対 して，R群では吻合不全を 1 例に, 肝膿瘍を 1 例に 認めたが，両群間に有意差はなかった (Table 3$) 。$

術後症状：聴き取り調查が十分に行われた症例 に限ると, 術後12力月以内に逆流症状を呈した割 合はP群 $44.4 \%$ ( 9 例中 4 例)，R群 $66.7 \%$ ( 9 例中 6 例）であり, 術後12力月から 24 力月の間に逆流 症状を呈した割合はP群 $25.0 \%$ (12例中 3 例), R群 $60.0 \%$ (10例中 6 例) とややR群に多かった。術後 12 力月以内の嘔吐症状の有無に関してはP群 16.7 $\%$ (12例中 2 例)， R群 $42.9 \%$ (14例中 6 例）に術 後嘔吐症状を認めた。またdumping症状について は, 術後 6 力月目にP群 $0 \%$ ( 4 例中 0 例), R群 $25.0 \%$ (8 例中 2 例), 術後12力月目にP群 $75.0 \%$ ( 4 例中 3 例), R群 $60.0 \%$ （5 例中 3 例）が訴之 た。なお術後 24 力月上については，いずれの症 状の項目も症例数が少なく評価が困難であった が，両群間に差は認めなかった。 


\section{考察}

近年，術前診断技術の向上により噴門部・上部 早期胃癌症例が増加してきており1)，これに対す る外科的治療としては噴門側胃切除術か胃全摘術 が選択される。噴門側胃切除術は縮小手術として の価值を評価されてきていることや，器械吻合の 多用による術式の簡便さ ${ }^{5}$ から普及してきてはい るものの，いまだ術式に対する評価が一定ではな く，限られた施設でしか施行されていないのが現 状である。

噴門側胃切除術と胃全摘術の比較においては術 後愁訴, dumping症状の面で, 噴門側胃切除術の方 が胃全摘術より有利であるという報告があ $\eta^{6) \sim 8)}$, 術後の消化吸収や消化管ホルモンの分泌 状態，患者満足度においても噴門側胃切除術の方

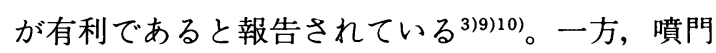
側胃切除術は胃全摘術よりも術後逆流症状が多い との意見 ${ }^{10)}$ もり, 再建術式の優劣においては議 論が分かれるところである。当科では噴門側胃切 除術に空腸pouch間置再建法を採用しており,こ の術式が栄養面・体重変化の観点から患者の術後 QOLにどのような影響を与えるかを，胃全摘・

Roux-en-Y再建術と比較検討した。

周術期因子に関しては, 手術時間がP群におい てやや長く, pouchの作製を含め, 吻合個所が多い ことが影響していると思われた。一方, 術後在院 日数はP群において有意に短く, 術後合併症の頻 度に両群間で差がないことから, 術後早期回復の 面でP群はR群よりも有利である。R群で術後合併 症を併発した 2 例を除いた両群間の比較でも R群 の術後在院日数は28.5日とP群より長かった。

術後の消化吸収に関しては, 胃全摘術では胆汁 や膵液の分泌低下が惹起され，消化吸収に不利で あると考えられている ${ }^{10)}$ 。脂肪吸収試験において も，食物が十二指腸を通るような経十二指腸的再 建法において脂肪吸収が良好であると報告されて いる ${ }^{101111}$ 。Vitamin B12吸収に関しては, 当然の事 ながら胃全摘術より噴門側胃切除術の方が有利で ある。今回の検討では術後の栄養指標因子におい て, 術後18力月目のHb值以外に両群間に差はみら れなかった。術前 $\mathrm{Hb}$ 値に両群間で有意差を認めて
いるため正確な術後評価を行うことは出来ない が，噴門側胃切除術において，残胃からのガスト リンおよび胃酸分泌により，鉄吸収が胃全摘術よ ク良好であることが予想され, 結果として Hb值に 差が出たことが考えられた。

術後の体重変化に関して, 噴門側胃切除術と胃 全摘術の比較では, 噴門側胃切除後の再建法は多 岐にわたっているが食事捸取量, 体重変動の面で 噴門側胃切除術が有利であるという報告 ${ }^{1012)}$ が多 い。今回の検討では術後 6 力月および12力月にお けるP群の術後体重減少率がR群より有意に少な く, 術後 24 力月でも同様の傾向がみられ, 従来の 報告結果が確認された。なお術後30力月および36 カ月においても, 症例数が少なくなり有意差はな いが, $\mathrm{P}$ 群の術後体重減少率がR群より若干少ない 傾向にあった。藪崎ら ${ }^{1)}$ 術後 2 年までに関して 同様の結果を報告しており, 空腸 pouch間置再建 法を用いると絶対的な貯留能が胃全摘術より多く なることが, 術後の食事捸食量や体重変化に対し て良好に働いていると考えられた。P群において, 迷走神経肝枝・腹腔枝を温存していることが, 術 後の食事攝取量・体重減少率に何らかの影響を及 ぼしている可能性がある。

機能面に関しては，噴門側胃切除術では噴門部 逆流防止機構の破綻による術後の逆流性食道炎が 問題であり, 胃全摘術に比べより胸やけが多いと されている3110)。今回の結果では逆にR群において 逆流性食道炎の発症が多い傾向にあり, P群で逆 流防止機能が劣っているとは判定されなかった。 仙丸ら ${ }^{5} は$, 噴門側胃切除後の空腸間置再建法と 空腸pouch間置再建法との比較においては, 両群 間で手術時間・術後在院日数に差はなく, 術後症 状（上腹部痛・嘔吐・つか之感）や術後食事捸取 量, 術後体重変化において空腸pouch間置再建法 が空腸間置再建法より有利であるとしている。ま た，噴門側胃切除後の再建に空腸pouchを用いる ことは, 術後の内視鏡・X線による残胃・十二指腸, 膵・胆道系の観察が容易になる ${ }^{13)}$ 。胃癌の好発部位 である残胃の検索が容易であることは絶対的に有 利な点であり, 今回の結果と合わせても, 噴門側 胃切除・空腸pouch間置再建術は上部早期胃癌に 対する有効な術式の 1 つであると考えられた。 


\section{参考文献}

1）藪崎 裕, 梨本 篤, 田中乙雄他: U領域早期胃 癌に対する噴門部胃切除術, 空腸囊間置再建法の 臨床的検討. 日消外会誌 $34: 1568-1576,2001$

2) Hus C, Chen C, Hsieh Y, et al: Esophageal reflux after total or proximal gastrectomy in patients with adenocarcinoma of the gastric cardia. Am J Gastroenterol 92 : 1347-1350, 1997

3）松尾 浩, 山村義孝, 高橋孝夫他: 術後のquality of lifeからみた噴門側胃切除と胃全摘の比較。日 臨外会誌58：1717-1722，1997

4) 日本胃癌学会：胃癌取扱い規約. 改訂第13版, 金 原出版, 東京, 1999

5）仙丸直人, 森田高行, 宮坂祐司他: 噴門側胃切除 における空腸間置法と空腸囊間置法との比較検 討. 日消外会誌32：2309-2313，1999

6) Mikulicz J : Beitrage zur technik der operation des magencarcinoma. Verh Dtsch Ges Chir 27 : 252-260, 1898
7）太田恵一郎, 中島聰總：胃癌手術とQOL。Oncologia $27: 251-257,1994$

8）大内慎一郎, 瀬戸泰士, 花岡農夫他：上部早期胃 癌に対する噴門側胃切除例の臨床的検討とQOL の評価。日臨外会誌 $57 ： 2370-2374,1996$

9）水本 清, 古本豊和, 野坂仁愛: 胃上部癌の治療 方針一根治性ならびに消化管ホルモン動態より みた手術術式の選択一。目消外会誌20：970-974, 1987

10）原田和則, 三隅厚信, 三隅克毅他：胃上部癌の手 術方針一とくに噴門部胃切除と胃全摘の術後遠 隔成績を中心に一. 日消外会誌 $20 ： 965-969,1987$

11）赤木正信, 三隅厚信, 馬場憲一郎：噴門側胃切除 術の障害と対策. 消外 $3: 1689-1698,1980$

12）早瀬仁滋, 鈴木和信, 山崎達之他：C領域胃癌の手 術·再建術式と適応. 手術50：2049-2056, 1996

13）亀山仁人, 鈴木 晃, 竹下明子他：胃切除後後再 建術一特にpouch形成の意義一 6 . 噴門側胃切除 後. 日外会誌 $98: 555-559,1977$ 